\title{
SIMULASI MONTE CARLO UNTUK MEMPREDIKSI JUMLAH KUNJUNGAN PASIEN
}

\author{
Muhamad Apri ${ }^{1)}$ Dasril Aldo ${ }^{2)}$ Hariselmi ${ }^{3)}$ \\ ${ }^{123)}$ Sistem Informasi, STMIK GICI, Batam \\ E-mail: muhamadapri10@gmail.com, dasrilaldo1994@gmail.com, hariselmi1@ gmail.com
}

\begin{abstract}
Abstrak
Pusat Kesehatan Masyarakat (Puskesmas) menjadi primadona bagi masyarakat untuk memperoleh pelayanan kesehatan. Puskesmas pada suatu kedaan dan waktu tertentu dapat dikunjungi oleh pasien yang datang secara massal dalam waktu bersamaan, menyebabkan aktivitas pelayanan kesehatan menjadi terhambat, terganggu dan kurang optimal. Akibatnya pasien tidak mendapatkan pelayanan secara menyeluruh, bahkan ada pasien yang menunggu terlalu lama dalam antrian. Untuk mengantisipasi hal tersebut perlu dilakukan simulasi untuk memprediksi jumlah kunjungan mungkin terjadi dimasa mendatang. Metode yang digunakan dalam penelitian ini adalah Monte Carlo. Tujuan penelitian ini adalah untuk memberikan informasi kepada pihak Puskesmas tentang prediksi jumlah kunjungan pasien yang kemunkinan terjadi dimasa akan datang. Data yang digunakan adalah data jumlah kunjungan pasien tahun 2016, 2017 dan 2018 pada Pusekesmas Air haji. Hasil dari penelitian ini adalah prediksi jumlah kunjungan pasien masa akan datang dengan tingkat akurasi rata-rata $91 \%$ dan $71 \%$. Sehingga, informasi ini bisa menjadi rujukan bagi pihak Puskesmas mengambil tindakan dan kebijakan untuk memperbaiki kualitas pelayanan.
\end{abstract}

Kata kunci: Monte Carlo, Simulasi, Pasien, Prediksi, Angka Acak.

\begin{abstract}
Community Health Centers (Puskesmas) are excellent for the community to obtain health services. When the health center and at a certain time can be visited by patients who come in bulk at the same time, causing health service activities to be hampered, disrupted and less than optimal. Furthermore, patients wait to queue. To consider this, a simulation is needed to estimate the number of visits that might occur in the future. The method used in this study is Monte Carlo. The purpose of this study is to provide information to the Puskesmas regarding the estimated number of possible patient visits in the future. The data used are data on the number of patient visits in 2016, 2017 and 2018 at the Water Hajj Community Health Center. The results of this study are estimates of the number of future patient visits with an average assessment rate of $91 \%$ and $71 \%$. Needed, this information can be a reference for the Puskesmas who take actions and policies to improve service quality.
\end{abstract}

Keywords: Monte Carlo, Simulation, Patients, Prediction, Random Numbers. 


\section{PENDAHULUAN}

Pusat Kesehatan Masyarakat (Puskesmas) merupakan suatu organisasi kesehatan fungsional. Puskesmas merupakan unit kesehatan yang didanai oleh pemerintah dan merupakan unit kesehatan yang didanai oleh pemerintah dan merupakan unit yang menjadi rujukan masyarakat dalam melakukan pemeriksaan kesehatan. Sebagai fasilitas kesehatan pertama dalam memberikan pelayanan kesehatan dalam suatu wilayah kerja, Puskesmas sering dikunjungi oleh banyak pasien yang dating sekaligus dalam waktu bersamaan. Jumlah kunjungan pasien yang terlalu banyak tersebut terkadang berbanding terbalik dengan tenaga kesehatan yang sedang bertugas, hak ini menyebabkan pelayanan kesehatan yang berlangsung menjadi kurang optimal.

Berdasarkan masalah di atas, untuk itu perlu dilakukan sebuah simulai untuk memprediksi jumlah kunjungan pasien yang akan berkunjung ke Puskesmas. Salah satu metode yang dapat digunakan untuk melakukan prediksi tersebut adalah metode Monte Carlo. Model simulasi Monte Carlo merupakan bentuk simulasi probabilistic dimana solusi dari suatu masalah diberikan berdasarkan proses randomisasi (acak).

Dalam penerapannya, simulasi Monte Carlo ini menggunakan data yang sudah ada (historical data) sebagai data training. Dengan kata lain, apabila ingin mengguanakan model simulasi yang di dalamnya terdapat random dan sampling dengan distribusi probabilitas yang dapta diketahui maka cara simulasi Monte Carlo ini dapat digunakan. Dalam simulasi Monte Carlo sebuah model dibangun berdasarkan sistem yang sebenarnya. Setiap variabel dalam model tersebut mempunyai nilai yang memiliki probabilitas dari masingmasing variable. Metode Monte Carlo mensimulasikan sistem tersebut berulangulang kali, ratusan bahkan sampai ribuan kali tergantung sistem yang ditinjau, dengan cara memilih sebuah nilai acak untuk setiap variabel dari distribusi probabilitasnya. Hasil yang didapatkan dari simulasi tersebut adalah sebuah distribusi probabilitas dari nilai sebuah sistem secara keseluruhan.

Simulasi Monte Carlo memiliki sifat dasar stokastik yang artinya metode ini berdasarkan pada penggunaan angka-angka yang bersifat acak (random number) dan kemungkinan untuk mengidentifikasi sebuah masalah, metode ini sebelumnya digunakan untuk menyelesaikan masalah kuantitatif dengan proses fisik. Seperti pelemparan dadu atau pencocokan kartu untuk menurunkan sampel.

Dasar dari metode Monte Carlo adalah percobaan berbagai elemen kemungkinan dengan menggunakan sampel acak. Keunggulan dari metode Monte Carlo ini merupakan alat perhitungan numerik yang kuat untuk mensimulasikan data statistik, simulasi ini memperoleh nilai keakuratan secara akurat dari bentuk fisik sistem yang dapat diamati.

\section{LANDASAN TEORI}

\section{Pemodelan}

Pemodelan (modeling) adalah proses merancang piranti lunak sebelum melakukan pengkodean (coding). Model piranti lunak dapat dianalogikan seperti pembuatan blueprint pada pembangunan gedung. Pemodelan merupakan proses untuk membuat sebuah model dari sistem. Model adalah representasi dari sebuah bentuk nyata, sedangkan sistem adalah saling keterhubungan anatar elemen yang membangun sebuah kesatuan, biasanya dibangun untuk mencapai tujuan tertentu. Tujuan suatu pemodelan adalah untuk 
menganalisa dan memberi prediksi yang dapat mendekati kenyataan sebelum sistem diterapkan di lapangan

\section{Simulasi}

Simulasi merupakan suatu teknik meniru operasi-operasi atau proses-proses yang terjadi dalam suaatu sistem dengan bantuan perangkat komputer. Untuk melihat bagaimana sistem tersebut bekerja maka dibuat asumsi-asumsi, dimana asumsi-asumsi tersebut biasanya berbentuk hubungan logika yang akan membentuk model, hubungan logika tersebut digunakan untuk mendapatkan pemahaman bagaimana perilaku hubungan dari sistem tersebut. Simulasi merupakan alat yang tepat untuk digunakan terutama jika diharuskan untuk melakukan eksperimen dalam rangka mencari komentar terbaik dari komponen-komponen sistem.

Pendekatan simulasi harus diawali dengan pembangunan model sistem nyata, model tersebut harus dapat menunjukkan bagaimana berbagai komponen dalam sistem saling berinteraksi sehingga benarbenar menggambarkan perilaku sistem. Setelah model dibuat makan model tersebut ditransformasikan ke dalam program komputer sehingga memungkinkan untuk disimulasikan.

\section{Model}

Model adalah suatu deskripsi atau analogi yang diguanakan untuk membatnu menggambarkan sesuatu yang tidak dapat diamati secara langsung. Pada umumnya model didefinisikan sebagai suatu sistem nyata. Model dikembangkan untuk melakukan investigasi/penelitian yang nantinya akan diterapkan pada sistem nyata atau untuk menangkap aspek perilaku tertentu dari sistem, dengan tujuan untuk memperoleh pengetahuan dari sistem tersebut.
Model dapat diklasifikasikan menjadi model ikonik, model analog dan model simbolik. Model ikonik adalah model yang mempresentasikan suatu sistem atau benda menjadi suatu objek model yang berwujud menyerupai sistem tersebut. Model analog adalah model yang mampu mempresentasikan sifat suatu sistem mejadi lebih sederhana. Model simbolik atau model matematis adalah representasi secara abstrak dari suatu sistem.

\section{Model Simulasi}

Model simulasi merupakan suatu perangkat uji coba yang menerapkan beberapa aspek penting, termasuk data masa lalu, untuk memberikan alternatif dalam mendukung keputusan. Simulasi merupakan suatu teknik meniru operasioperasi atau proses-proses yang terjadi dalam suatu sistem dengan bantuan perangkat komputer dan dilandasi oleh beberapa asumsi tertentu sehingga sistem tersebut bisa dipelajari secara ilmiah.

\section{Simulasi Monte Carlo}

Simulasi Monte Carlo didefinisikan sebagai teknik sampling statistik yang digunakan untuk memperkirakan solusi terhadap masalah-masalah kuantitatif. Dalam simulasi Monte Carlo sebuah model dibangun berdasarkan sistem yang sebenarnya. Setiap variabel dalam model tersebut memiliki nilai probabilitas yang berbeda, yang ditunjukkan oleh distribusi probabilitas dari setiap variabel. Metode Monte Carlo mensimulasikan sistem tersebut berulang kali berdasrkan sistem yang ditinjau.

Simulasi monte carlo harus dilakukan dengan menggunakan model komputer untuk meniru kehidupan nyata atau membuat prediksi. Bila diciptakan suatu model dengan satu spreadsheet seperti 
excel, maka dipunyai sejumlah tertentu parameter masukan dan beberapa persamaan yang menggunakan masukan terseut untuk memberikan sekumpulan keluaran

Dasar dari simulasi monte carlo adalah percobaan elemen kemungkinan dengan menggunakan sampel acak (random). Metode ini terbagi dalam 5 tahapan:

1. Menetapkan Distribusi Probabilitas.

2. Menghitung distribusi probabilitas kumulatif.

3. Menetapkan interval angka acak untuk tiap variabel.

4. Membangkitkan angka acak.

5. Membuat simulasi dari rangkaian percobaan.

\section{PHP (Hypertext Preprocessor)}

PHP pertama kali diciptakan oleh Rasmus Lerdorf pada tahun 1995. PHP merupakan bahasa scripting yang open source, yang cocok untuk pengembangan web dan dapat disisipkan ke dalam HTML. PHP mendukung pertukaran data kompleks antar seluruh bahasa pemrograman web. Mengenai interkoneksi, PHP mendukung penggunaan objek java sebagai objek php secara transparan.

Untuk pengolahan informasi basis data, PHP menggunakan fungsi-fungsi yang memilikikesamaan dengan sintak SQL (Structured Query Language). Fungsifungsi dirancang untuk dikenali oleh server basis data yang dipakai, terutama oleh server basis data MYSQL.

PHP dappat digunakan pada semua sistem operasi, antara lain Linux, Unix, Microsoft Windows, Mac OS, RISC OS. PHP juga mendukung web server seperti Apache, audium, Xitami, OmniHTTPd, dan masih bantak lainnya, bahkan PHP dapat bekerja sebagai suatu CGI processor. PHP tidak terbatas pada hasil keluaran HTML. PHP juga memiliki kemapuan untk mengolah keluaran gambar, file PDG, dan movies Flash. PHP juga dapat menghasilkan teks seperti XHTML dan file XML lainnya.

\section{METODE PENELITIAN}

Kerangka kerja penelitian ini merupakan langkah-langkah yang akan dilakukan dalam penyelesaian masalah yang akan dibahas. Adapun kerangka kerja penelitian ini dapat digambarkan pada gambar 1 berikut:

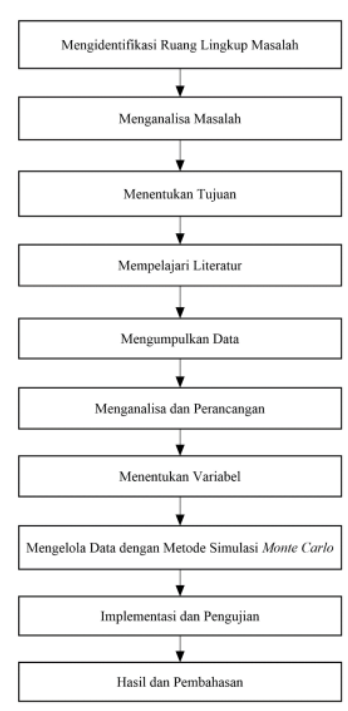

Gambar 1. Kerangka Kerja penelitian

\section{HASIL DAN PEMBAHASAN}

\section{Persiapan Data}

Pada penelitian ini, data utama yang digunakan adalah data tahun 2016, 2017 dan 2018 dimulai dari bulan januari sampai bulan desember. Variabel yang digunakan dalam penelitian ini yaitu jumlah kunjungan pasien Puskesmas perbulannya. Data tahun 2016 digunakan sebagai data training untuk memprediksi tahun 2017, 
data tahun 2017 digunakan sebagai data training untuk memprediksi tahun 2018, dan data 2018 digunakan sebagai data training untuk memprediksi tahun 2019. Data jumlah kunjungan pasien dapat dilihat pada tabel 1 di bawah ini.

Tabel 1. Data Jumlah Kunjungan

\begin{tabular}{|c|c|c|c|}
\hline Bulan & $\mathbf{2 0 1 6}$ & $\mathbf{2 0 1 7}$ & $\mathbf{2 0 1 8}$ \\
\hline Januari & 1752 & 1592 & 1268 \\
\hline Februari & 1726 & 1377 & 1230 \\
\hline Maret & 1432 & 1201 & 1532 \\
\hline April & 1609 & 1525 & 1702 \\
\hline Mei & 1562 & 1434 & 1418 \\
\hline Juni & 1367 & 1342 & 1239 \\
\hline Juli & 1372 & 1346 & 3295 \\
\hline Agustus & 1538 & 1974 & 4374 \\
\hline September & 1424 & 1752 & 2507 \\
\hline Oktober & 1578 & 1327 & 2253 \\
\hline November & 1228 & 1489 & 2389 \\
\hline Desember & 1148 & 1675 & 2155 \\
\hline Total & 17736 & 18034 & 18034 \\
\hline
\end{tabular}

(Sumber: UPT Puskesmas Air Haji, 2018)

Tahapan Perhitungan Dengan Metode Simulasi Monte Carlo

1. Membuat distribusi Probabilitas

Distribusi Probabilitas menggambarkan peluang dari variabel yang ada. Nilai probabilitas dapat diperoleh dengan cara membagi frekuensi dengan total frekuensi.

Menghitung nilai probabilitas untuk untuk data tahun 2016.

Tabel 2. Tabel Distribusi Probabilitas

Tahun 2016

JURSIMA

Jurnal Sistem Informasi dan Manajemen

\begin{tabular}{|c|c|c|}
\hline Bulan & Frekuensi & Probabilitas \\
\hline Januari & 1752 & $\begin{array}{c}\mathrm{P} 1= \\
1752 / 17736= \\
0.10\end{array}$ \\
\hline Februari & 1726 & $\begin{array}{c}\mathrm{P} 2= \\
1726 / 17736= \\
0.10\end{array}$ \\
\hline Maret & 1432 & $\begin{array}{c}\mathrm{P} 3= \\
1432 / 17736= \\
0.08\end{array}$ \\
\hline April & 1609 & $\begin{array}{c}\mathrm{P} 4= \\
1609 / 17736= \\
0.09\end{array}$ \\
\hline Mei & 1562 & $\begin{array}{c}\mathrm{P} 5= \\
1562 / 17736= \\
0.09\end{array}$ \\
\hline Juni & 1367 & $\begin{array}{c}\mathrm{P} 6= \\
1367 / 17736= \\
0.08\end{array}$ \\
\hline Juli & 1372 & $\begin{array}{c}\mathrm{P} 7= \\
1372 / 17736= \\
0.08\end{array}$ \\
\hline Agustus & 1538 & $\begin{array}{c}\mathrm{P} 8= \\
1538 / 17736= \\
0.09\end{array}$ \\
\hline September & 1424 & $\begin{array}{c}P 9= \\
1424 / 17736= \\
0.08\end{array}$ \\
\hline Oktober & 1578 & $\begin{array}{c}\mathrm{P} 10= \\
1148 / 17736= \\
0.06\end{array}$ \\
\hline November & 1228 & $\begin{array}{c}\mathrm{P} 11= \\
1578 / 17736= \\
0.09\end{array}$ \\
\hline Desember & 1148 & $\begin{array}{c}\mathrm{P} 12= \\
1228 / 17736= \\
0.07\end{array}$ \\
\hline Total & 17736 & 1 \\
\hline
\end{tabular}

Menghitung nilai probabilitas untuk untuk data tahun 2017 
Tabel 3. Tabel Distribusi Probabilitas

Tahun 2017

\begin{tabular}{|c|c|c|}
\hline Bulan & Frekuensi & Probabilitas \\
\hline Januari & 1592 & $\begin{array}{c}\mathrm{P} 1= \\
1592 / 18034= \\
0.09\end{array}$ \\
\hline Februari & 1377 & $\begin{array}{c}\mathrm{P} 2= \\
1377 / 18034= \\
0.08\end{array}$ \\
\hline Maret & 1201 & $\begin{array}{c}\mathrm{P} 3= \\
1201 / 18034= \\
0.07\end{array}$ \\
\hline April & 1525 & $\begin{array}{c}\mathrm{P} 4= \\
1525 / 18034= \\
0.08\end{array}$ \\
\hline Mei & 1434 & $\begin{array}{c}\mathrm{P} 5= \\
1434 / 18034= \\
0.08\end{array}$ \\
\hline Juni & 1342 & $\begin{array}{c}\text { P6 }= \\
1342 / 18034= \\
0.07\end{array}$ \\
\hline Juli & 1346 & $\begin{array}{c}\mathrm{P} 7= \\
1346 / 18034= \\
0.07\end{array}$ \\
\hline Agustus & 1974 & $\begin{array}{c}\mathrm{P} 8= \\
1974 / 18034= \\
0.11\end{array}$ \\
\hline September & 1752 & $\begin{array}{c}\mathrm{P} 9= \\
1752 / 18034= \\
0.10\end{array}$ \\
\hline Oktober & 1327 & $\begin{array}{c}\mathrm{P} 10= \\
1327 / 18034= \\
0.07\end{array}$ \\
\hline November & 1489 & $\begin{array}{c}\mathrm{P} 11= \\
1489 / 18034= \\
0.08\end{array}$ \\
\hline Desember & 1675 & $\begin{array}{c}\mathrm{P} 12= \\
1675 / 18034= \\
0.09\end{array}$ \\
\hline
\end{tabular}

\section{Total}

18034

0.99

Menghitung nilai probabilitas untuk untuk data tahun 2018

Tabel 4. Tabel Distribusi

Probabilitas Tahun 2018

\begin{tabular}{|c|c|c|}
\hline Bulan & Frekuensi & Probabilitas \\
\hline Januari & 1268 & $\begin{array}{c}\mathrm{P} 1 \\
=1268 / 25362 \\
=0.05\end{array}$ \\
\hline Februari & 1230 & $\begin{array}{c}\mathrm{P} 2 \\
=1230 / 25362 \\
=0.05\end{array}$ \\
\hline Maret & 1532 & $\begin{array}{c}\mathrm{P} 3= \\
1532 / 25362= \\
0.06\end{array}$ \\
\hline April & 1702 & $\begin{array}{c}\mathrm{P} 4 \\
=1702 / 25362 \\
=0.07\end{array}$ \\
\hline Mei & 1418 & $\begin{array}{c}P 5= \\
1418 / 25362= \\
0.06\end{array}$ \\
\hline Juni & 1239 & $\begin{array}{c}\mathrm{P} 6= \\
1239 / 25362= \\
0.05\end{array}$ \\
\hline Juli & 3295 & $\begin{array}{c}\mathrm{P} 7= \\
3295 / 25362= \\
0.13\end{array}$ \\
\hline Agustus & 4374 & $\begin{array}{c}\mathrm{P} 8= \\
4374 / 25362= \\
0.17\end{array}$ \\
\hline September & 2507 & $\begin{array}{c}\mathrm{P} 9= \\
2507 / 25362= \\
0.10\end{array}$ \\
\hline Oktober & 2253 & $\begin{array}{c}\mathrm{P} 10= \\
2253 / 25362= \\
0.09\end{array}$ \\
\hline November & 2389 & $\begin{array}{c}\mathrm{P} 11= \\
2389 / 25362= \\
0.09\end{array}$ \\
\hline
\end{tabular}




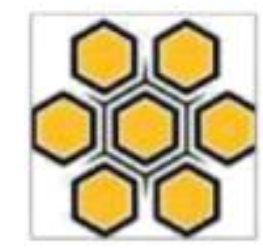

\begin{tabular}{|c|c|c|}
\hline Desember & 2155 & $\begin{array}{c}\mathrm{P} 12= \\
2155 / 25362= \\
0.08\end{array}$ \\
\hline Total & 25362 & 1 \\
\hline
\end{tabular}

\begin{tabular}{|c|c|c|c|}
\hline $\begin{array}{c}\text { Desem } \\
\text { ber }\end{array}$ & 1148 & 0.07 & 1 \\
\hline Total & 17736 & 1 & - \\
\hline
\end{tabular}

2. Membangun distribusi probabilitas

Distribusi probabilitas kumulatif untuk kumulatif

Distribusi probabilitas kumulatif diperoleh dari hasil penjumlahan nilai distribusi probabilitas dengan jumlah nilai distribusi probabilitas sebelumnya, kecuali untuk nilai distribusi probabilitas kumulatif yang pertama. Dimana nilai probabilitas kumulatifnya sama dengan nilai probabilitas variabel itu sendiri.

Distribusi probabilitas kumulatif untuk data tahun 2016

Tabel 5. Tabel Distribusi Probabilitas

Kumulatif Tahun 2016

\begin{tabular}{|c|c|c|c|}
\hline Bulan & $\begin{array}{c}\text { Frekue } \\
\text { nsi }\end{array}$ & $\begin{array}{c}\text { Probabil } \\
\text { itas }\end{array}$ & $\begin{array}{c}\text { Kumul } \\
\text { atif }\end{array}$ \\
\hline Januari & 1752 & 0.10 & 0.10 \\
\hline $\begin{array}{c}\text { Februar } \\
\text { i }\end{array}$ & 1726 & 0.10 & 0.20 \\
\hline Maret & 1432 & 0.08 & 0.28 \\
\hline April & 1609 & 0.09 & 0.37 \\
\hline Mei & 1562 & 0.09 & 0.46 \\
\hline Juni & 1367 & 0.08 & 0.54 \\
\hline Juli & 1372 & 0.08 & 0.62 \\
\hline $\begin{array}{c}\text { Agustu } \\
\text { s }\end{array}$ & 1538 & 0.09 & 0.71 \\
\hline $\begin{array}{c}\text { Septem } \\
\text { ber }\end{array}$ & 1424 & 0.08 & 0.79 \\
\hline $\begin{array}{c}\text { Oktobe } \\
\text { r }\end{array}$ & 1578 & 0.06 & 0.85 \\
\hline $\begin{array}{c}\text { Novem } \\
\text { ber }\end{array}$ & 1228 & 0.09 & 0.94 \\
\hline
\end{tabular}

Tabel 6. Tabel Distribusi Probabilitas

Kumulatif Tahun 2017

\begin{tabular}{|c|c|c|c|}
\hline Bulan & $\begin{array}{c}\text { Frekue } \\
\text { nsi }\end{array}$ & $\begin{array}{c}\text { Probabil } \\
\text { itas }\end{array}$ & $\begin{array}{c}\text { Kumul } \\
\text { atif }\end{array}$ \\
\hline Januari & 1592 & 0.09 & 0.09 \\
\hline $\begin{array}{c}\text { Februar } \\
\text { i }\end{array}$ & 1377 & 0.08 & 0.17 \\
\hline Maret & 1201 & 0.07 & 0.24 \\
\hline April & 1525 & 0.08 & 0.32 \\
\hline Mei & 1434 & 0.08 & 0.40 \\
\hline Juni & 1342 & 0.07 & 0.47 \\
\hline Juli & 1346 & 0.07 & 0.54 \\
\hline $\begin{array}{c}\text { Agustu } \\
\text { s }\end{array}$ & 1974 & 0.11 & 0.65 \\
\hline $\begin{array}{c}\text { Septem } \\
\text { ber }\end{array}$ & 1752 & 0.1 & 0.75 \\
\hline $\begin{array}{c}\text { Oktobe } \\
\text { r }\end{array}$ & 1327 & 0.07 & 0.82 \\
\hline $\begin{array}{c}\text { Novem } \\
\text { ber }\end{array}$ & 1489 & 0.08 & 0.90 \\
\hline $\begin{array}{c}\text { Desem } \\
\text { ber }\end{array}$ & 1675 & 0.09 & 0.99 \\
\hline Total & 18034 & 0.99 & - \\
\hline
\end{tabular}

Distribusi probabilitas kumulatif untuk data tahun 2018. 
Tabel 7. Tabel Distribusi Probabilitas

Kumulatif Tahun 2018

\begin{tabular}{|c|c|c|c|}
\hline Bulan & $\begin{array}{c}\text { Frekue } \\
\text { nsi }\end{array}$ & $\begin{array}{c}\text { Probabil } \\
\text { itas }\end{array}$ & $\begin{array}{c}\text { Kumul } \\
\text { atif }\end{array}$ \\
\hline Januari & 1268 & 0.05 & 0.05 \\
\hline $\begin{array}{c}\text { Februar } \\
\text { i }\end{array}$ & 1230 & 0.05 & 0.10 \\
\hline Maret & 1532 & 0.06 & 0.16 \\
\hline April & 1702 & 0.07 & 0.23 \\
\hline Mei & 1418 & 0.06 & 0.29 \\
\hline Juni & 1239 & 0.05 & 0.34 \\
\hline Juli & 3295 & 0.13 & 0.47 \\
\hline $\begin{array}{c}\text { Agustu } \\
\text { s }\end{array}$ & 4374 & 0.17 & 0.64 \\
\hline $\begin{array}{c}\text { Septem } \\
\text { ber }\end{array}$ & 2507 & 0.10 & 0.74 \\
\hline $\begin{array}{c}\text { Oktobe } \\
\text { r }\end{array}$ & 2253 & 0.09 & 0.83 \\
\hline $\begin{array}{c}\text { Novem } \\
\text { ber }\end{array}$ & 2389 & 0.09 & 0.92 \\
\hline $\begin{array}{c}\text { Desem } \\
\text { ber }\end{array}$ & 2155 & 0.08 & 1 \\
\hline \begin{tabular}{c} 
Total \\
\hline
\end{tabular} & 25362 & 1 & - \\
\hline
\end{tabular}

3. Menetapkan interval angka random (angka acak).

Interval angka random dibentuk berdasarkan nilai distribusi probabilitas kumulatif yang telah diperoleh pada tahap sebelumnya. Penetapan angka random dilakukan untuk setiap variabel, penggunaan interval angka random berfungsi sebagai pembatas antara variabel yang satu dengan variabel yang lain dan juga memberikan acuan hasil simulasi dari percobaan berdasarkan angka random yang dibangkitkan.

Tabel interval angka random untuk data tahun 2016
Tabel 8. Interval Angka Random Data

Tahun 2016

\begin{tabular}{|c|c|c|c|}
\hline \multirow{2}{*}{ Bulan } & \multirow{2}{*}{ Frekuensi } & \multicolumn{2}{|c|}{$\begin{array}{c}\text { Interval } \\
\text { Angka } \\
\text { Random }\end{array}$} \\
\cline { 2 - 4 } & & Min & Max \\
\hline Januari & 1752 & 1 & 10 \\
\hline Februari & 1726 & 11 & 20 \\
\hline Maret & 1432 & 21 & 28 \\
\hline April & 1609 & 29 & 37 \\
\hline Mei & 1562 & 38 & 46 \\
\hline Juni & 1367 & 47 & 54 \\
\hline Juli & 1372 & 55 & 62 \\
\hline Agustus & 1538 & 63 & 71 \\
\hline September & 1424 & 72 & 79 \\
\hline Oktober & 1578 & 80 & 85 \\
\hline November & 1228 & 86 & 94 \\
\hline Desember & 1148 & 95 & 100 \\
\hline Total & 17736 & & - \\
\hline
\end{tabular}

Tabel interval angka random untuk data tahun 2017

Tabel 9. Interval Angka Random Data

Tahun 2017

\begin{tabular}{|c|c|c|c|}
\hline \multirow{2}{*}{ Bulan } & \multirow{2}{*}{ Frekuensi } & \multicolumn{2}{|c|}{$\begin{array}{c}\text { Interval } \\
\text { Angka } \\
\text { Random }\end{array}$} \\
\cline { 3 - 4 } & & Min & Max \\
\hline Januari & 1592 & 1 & 9 \\
\hline Februari & 1377 & 10 & 17 \\
\hline Maret & 1201 & 18 & 24 \\
\hline April & 1525 & 25 & 32 \\
\hline Mei & 1434 & 33 & 40 \\
\hline Juni & 1342 & 41 & 47 \\
\hline Juli & 1346 & 48 & 54 \\
\hline
\end{tabular}




\begin{tabular}{|c|c|c|c|}
\hline Agustus & 1974 & 55 & 65 \\
\hline September & 1752 & 66 & 75 \\
\hline Oktober & 1327 & 76 & 82 \\
\hline November & 1489 & 83 & 90 \\
\hline Desember & 1675 & 91 & 99 \\
\hline Total & 18034 & \multicolumn{2}{|c|}{-} \\
\hline
\end{tabular}

Tabel interval angka random untuk data tahun 2018

Tabel 10. Interval Angka Random Data

Tahun 2018

\begin{tabular}{|c|c|c|c|}
\hline \multirow{2}{*}{ Bulan } & \multirow{2}{*}{ Frekuensi } & \multicolumn{2}{|c|}{$\begin{array}{c}\text { Interval } \\
\text { Angka } \\
\text { Random }\end{array}$} \\
\cline { 2 - 4 } & & Min & Max \\
\hline Januari & 1268 & 1 & 5 \\
\hline Februari & 1230 & 6 & 10 \\
\hline Maret & 1532 & 11 & 16 \\
\hline April & 1702 & 17 & 23 \\
\hline Mei & 1418 & 24 & 29 \\
\hline Juni & 1239 & 30 & 34 \\
\hline Juli & 3295 & 35 & 47 \\
\hline Agustus & 4374 & 48 & 64 \\
\hline September & 2507 & 65 & 74 \\
\hline Oktober & 2253 & 75 & 83 \\
\hline November & 2389 & 84 & 92 \\
\hline Desember & 2155 & 93 & 100 \\
\hline Total & 25362 & & - \\
\hline
\end{tabular}

4. Membangkitkan angka random (angka acak).

Setelah interval angka random dibentuk, selanjutnya pada tahap ini akan dibangkitkan angka random yang akan digunakan dalam simulasi. pada penelitian
Dengan menggunakan metode Mixed Congruent Method. Pada penelitian ini angka random akan dibangkitkan dengan menggunakan metode Mixed Congruent Method.

$$
\mathrm{Zi}+1=(\mathrm{a} * \mathrm{Zi}+\mathrm{c}) \bmod \mathrm{m}
$$

Dimana:

$\mathrm{a}=$ konstanta Pengali $(\mathrm{a}<\mathrm{m})$

$\mathrm{c}=$ konstanta pergeseran $(\mathrm{c}<\mathrm{m})$

$\mathrm{m}=$ konstanta modulus $(\mathrm{m}>0)$

$\mathrm{Zi}=$ bilangan awal (bilangan bulat $\geq 0, \mathrm{Z} 0$ $<\mathrm{m}$ )

Membangkitkan angka random dengan Mixed Congruent Method dibutuhkan 4 parameter yang nilainya harus di tetapkan terlebih dahulu yaitu a, c, $m$ dan Zi. Pada tahap ini parameter-parameter di atas selanjutnya akan diisi dengan value $\mathrm{a}=$ $23, \mathrm{c}=20, \mathrm{~m}=99, \mathrm{Zi}=22$. Setelah value dari parameter-parameter tersebut diisi, selanjutnya akan dilakukan perhitungan untuk membangkitkan bilangan acak seperti tabel di bawah ini.

Tabel 11. Angka Random

\begin{tabular}{|c|c|}
\hline $\begin{array}{c}\text { Simulasi } / \\
\text { Bulan }\end{array}$ & Random Number \\
\hline 1 & $\begin{array}{c}\mathrm{Z} 1=(23 * 22+20) \bmod \\
99=31\end{array}$ \\
\hline 2 & $\begin{array}{c}\mathrm{Z} 2=(23 * 31+20) \\
\bmod 99=40\end{array}$ \\
\hline 3 & $\begin{array}{c}\mathrm{Z} 3=(23 * 40+20) \\
\bmod 99=49\end{array}$ \\
\hline 4 & $\begin{array}{c}\mathrm{Z} 4=(23 * 49+20) \\
\bmod 99=58\end{array}$ \\
\hline 5 & $\begin{array}{c}\mathrm{Z} 5=(23 * 58+20) \\
\bmod 99=67\end{array}$ \\
\hline 6 & $\begin{array}{c}\mathrm{Z} 6=(23 * 67+20) \\
\bmod 99=76\end{array}$ \\
\hline
\end{tabular}




\begin{tabular}{|c|c|}
\hline 7 & $\begin{array}{c}\mathrm{Z} 7=(23 * 76+20) \\
\bmod 99=85\end{array}$ \\
\hline 8 & $\begin{array}{c}\mathrm{Z} 8=(23 * 85+20) \\
\bmod 99=94\end{array}$ \\
\hline 9 & $\begin{array}{c}\mathrm{Z} 9=(23 * 94+20) \\
\bmod 99=4\end{array}$ \\
\hline 10 & $\begin{array}{c}\mathrm{Z} 10=(23 * 4+20) \\
\bmod 99=13\end{array}$ \\
\hline 11 & $\begin{array}{c}\mathrm{Z} 11=(23 * 13+20) \\
\bmod 99=22\end{array}$ \\
\hline 12 & $\begin{array}{c}\mathrm{Z} 12=(23 * 22+20) \\
\bmod 99=31\end{array}$ \\
\hline
\end{tabular}

5. Membuat Simulasi Dari Rangkaian Percobaan

Simulasi dilakukan dengan cara memasukkan dan membandingkan angka random yang telah dibangkitkan pada tabel 4.13 dengan tabel interval angka random yang ada pada tabel 4.10 untuk data tahun 2016, tabel 4.11 untuk data tahun 2017 dan tabel 4.12 untuk data tahun 2018. Hasil dari simulasi data tahun 2016 akan digunakan untuk memprediksi kemungkinan jumlah kunjungan pasien yang terjadi pada tahun 2017, sedangkan hasil dari simulasi data tahun 2017 akan digunakan untuk memprediksi kemungkinan jumlah kunjungan pasien pada tahun 2018 dan hasil dari simulasi data tahun 2018 digunakan untuk memprediksi kemungkinan jumlah kunjungan pasien pada tahun 2019. Untuk lebih jelasnya hasil dari simulasi-simulasi tersebut dapat dilihat pada tabel di bawah ini.
Tabel 12. Hasil Simulasi Predksi

Jumlah Kunjungan

\begin{tabular}{|c|c|c|c|c|}
\hline Bulan & $\begin{array}{c}\text { Rand } \\
\text { om } \\
\text { Num } \\
\text { ber }\end{array}$ & 2017 & 2018 & 2019 \\
\hline Januari & 31 & 1609 & 1525 & 1239 \\
\hline$\underset{\text { ri }}{\text { Februa }}$ & 40 & 1562 & 1434 & 3295 \\
\hline Maret & 49 & 1367 & 1346 & 4374 \\
\hline April & 58 & 1372 & 1974 & 4374 \\
\hline Mei & 67 & 1538 & 1752 & 2507 \\
\hline Juni & 76 & 1424 & 1327 & 2253 \\
\hline Juli & 85 & 1148 & 1489 & 2389 \\
\hline $\begin{array}{c}\text { Agustu } \\
\text { s }\end{array}$ & 94 & 1578 & 1675 & 2155 \\
\hline $\begin{array}{c}\text { Septem } \\
\text { ber }\end{array}$ & 4 & 1752 & 1592 & 1268 \\
\hline $\begin{array}{c}\text { Oktobe } \\
\mathrm{r}\end{array}$ & 13 & 1726 & 1377 & 1532 \\
\hline $\begin{array}{l}\text { Novem } \\
\text { ber }\end{array}$ & 22 & 1432 & 1201 & 1702 \\
\hline $\begin{array}{c}\text { Desem } \\
\text { ber }\end{array}$ & 31 & 1609 & 1525 & 1239 \\
\hline \multicolumn{2}{|c|}{ Total } & $\begin{array}{c}1811 \\
7\end{array}$ & $\begin{array}{c}1821 \\
7\end{array}$ & $\begin{array}{c}2832 \\
7\end{array}$ \\
\hline \multicolumn{2}{|c|}{ Rata-rata } & $\begin{array}{c}1509 . \\
75\end{array}$ & $\begin{array}{c}1518 . \\
08\end{array}$ & $\begin{array}{c}2360 . \\
58\end{array}$ \\
\hline
\end{tabular}

Dari tabel di atas dapat disimpulkan bahwa total pasien yang berkunjung pada tahun 2017 adalah 18117 orang, dengan rata-rata kunjungan setiap bulannya yaitu 1510 pasien. Sedangkan untuk tahun 2018 total pasien yang berkunjung yaitu 18217 dengan rata-rata perbulannya sebanyak 1518 orang pasien, dan untuk tahun 2019 diperoleh total 28327 pasien, dengan ratarata perbulannya yaitu 2361 pasien. 


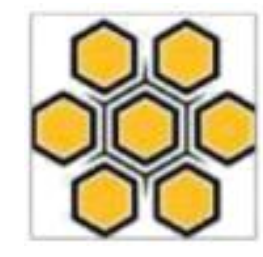

\begin{abstract}
Setelah tahapan analisis dan perancangan dilakukan, selanjutnya akan dilakukan implementasi ke dalam bentuk sistem yang terkomputerisasi, tujuannya adalah untuk memperlihatkan apakah hasil dari analisis yang telah dilakukan pada pembahasan sebelumnya sama dengan hasil yang diberikan oleh sistem yang dibangun.
\end{abstract}

6. Tampilan menu utama

Menu utama merupakan halaman awal yang tampil pada saat aplikasi dijalankan. Pada halaman ini terdapat beberapa pilihan menu yang dapat dipilih seperti yang terlihat pada gambar $5.1 \mathrm{di}$ bawah ini. Pilih 2017 jika ingin melakukan simulasi dan prediksi untuk tahun 2017, pilih 2018 untuk melakukan simulasi dan memprediksi untuk tahun 2018 dan pilih 2019 untuk melakukan simulasi dan memprediksi untuk tahun 2019.

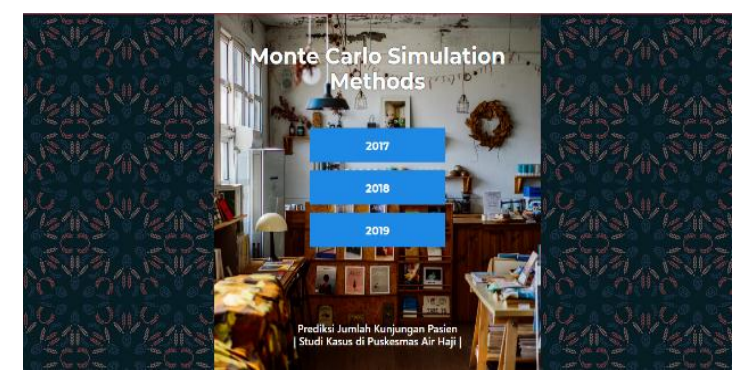

\section{Gambar 2. Menu Utama Sistem}

7. Tampilan halaman distribusi frekuensi

Pada tampilan halaman distribusi frekuensi ini ditampilakn frekuensi jumlah kunjungan pasien perbulannya berdasarkan data kunjungan yang ada pada bab sebelumnya.

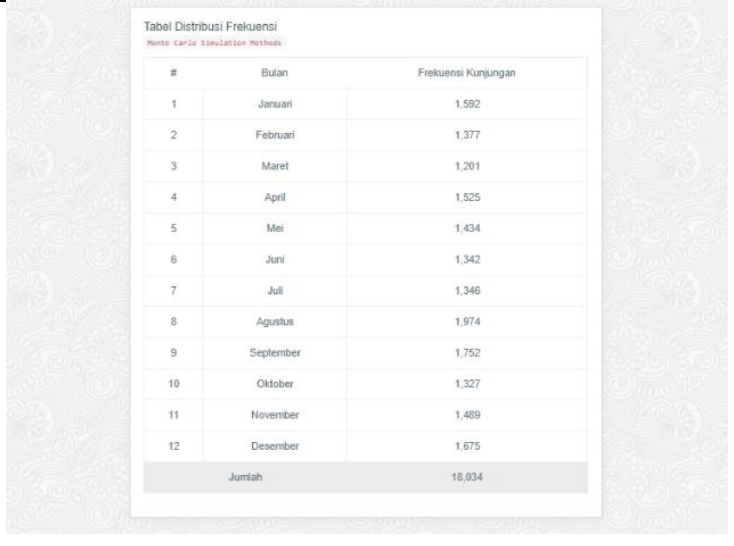

Gambar 3. Distribusi Frekuensi Target Tahun 2017

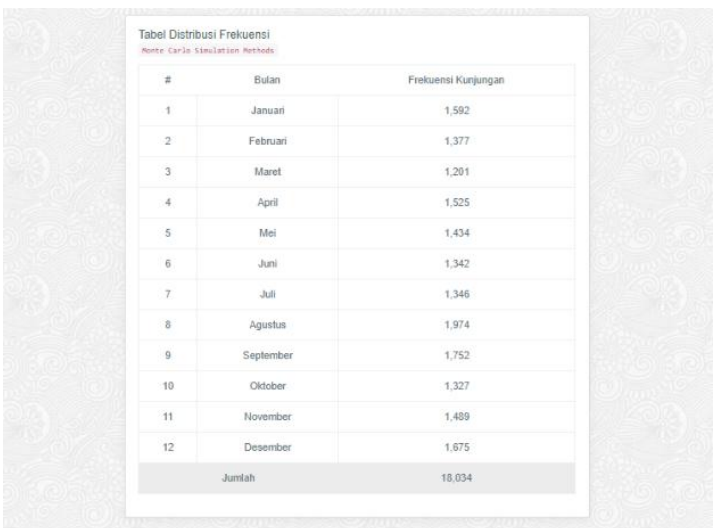

Gambar 4. Distribusi Frekuensi Target Tahun 2018

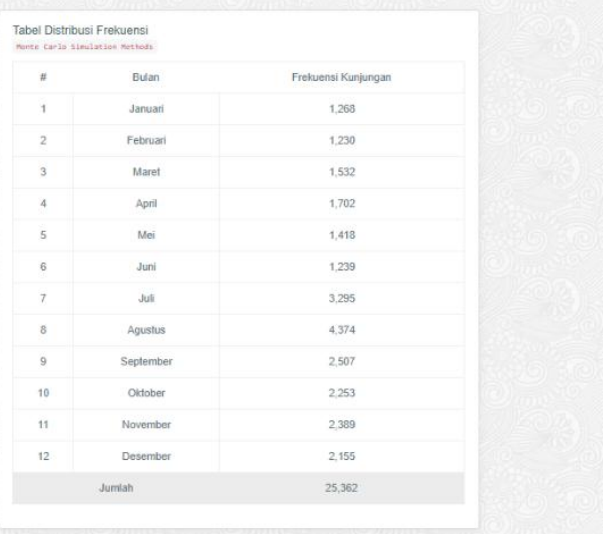
Gambar 5. Distribusi Frekuensi Target
Tahun 2019

8. Tampilan halaman distribusi probabilitas 


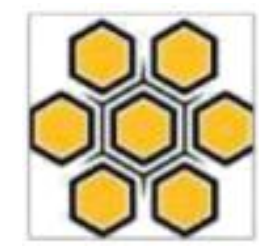

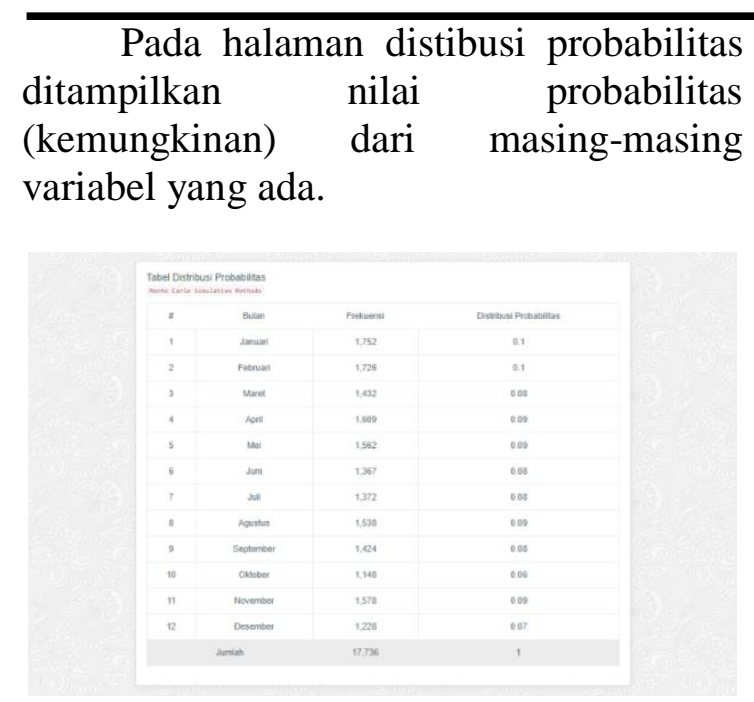

Gambar 6. Distribusi Probabilitas Target Tahun 2017

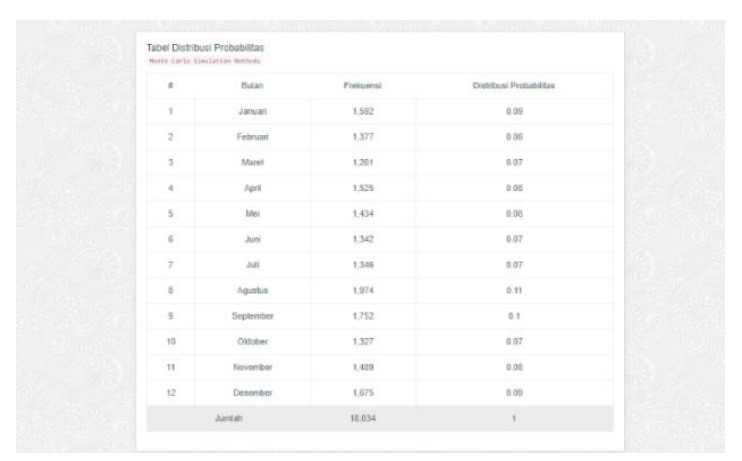

Gambar 7. Distribusi Probabilitas Target Tahun 2018

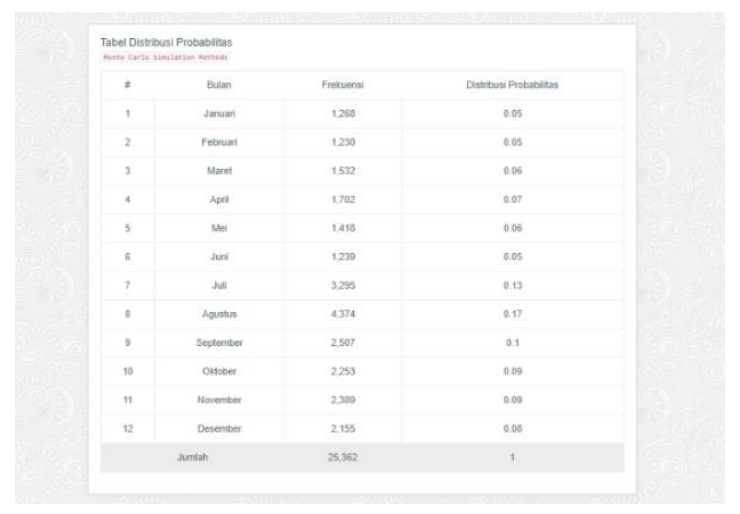

Gambar 8. Distribusi Probabilitas Target Tahun 2019
9. Tampilan distribusi probabilitas kumulatif
Nilai probabilitas kumulaitf diperoleh dari perhitungan hasil penjumlahan nilai probabilitas masing- masing variabel.

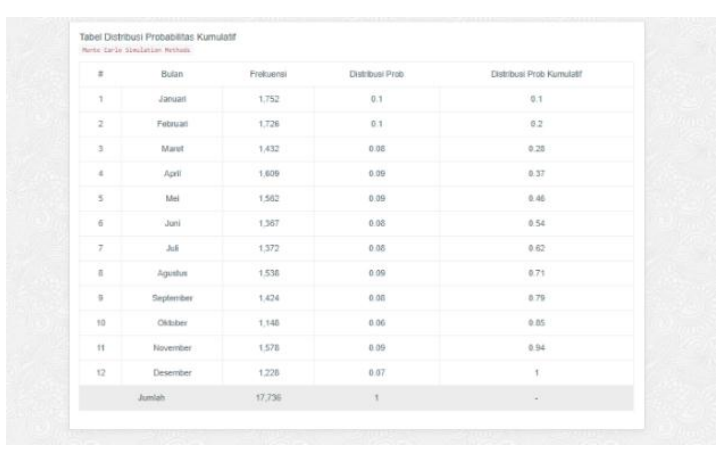

Gambar 9. Distribusi Probabilitas

Kumulatif Target Tahun 2017

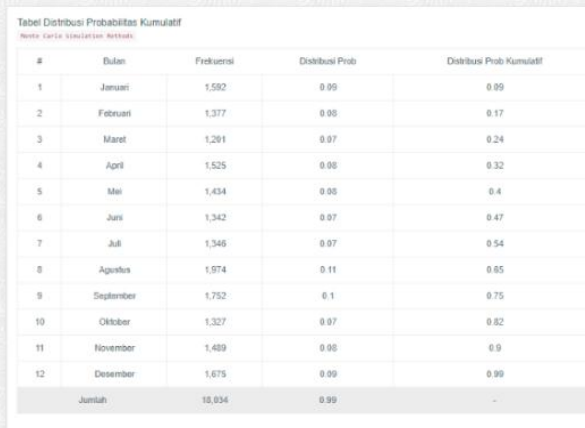

Gambar 10. Distribusi Probabilitas

Kumulatif Target Tahun 2018

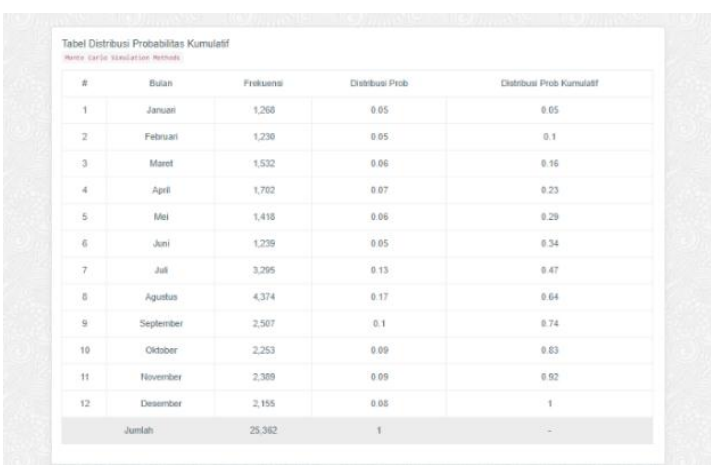

Gambar 11. Distribusi Probabilitas Kumulatif Target Tahun 2019 
10. Tampilan interval angka acak

Setelah nilai distribusi probabilitas kumulatif diperoleh, langkah selanjutnya adalah menetukan interval angka acak untuk masing-masing variabel yang ada.

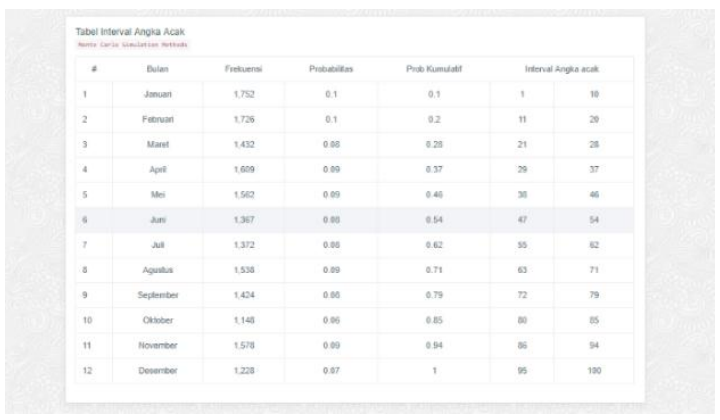

Gambar 12. Interval Angka Acak Target 2017

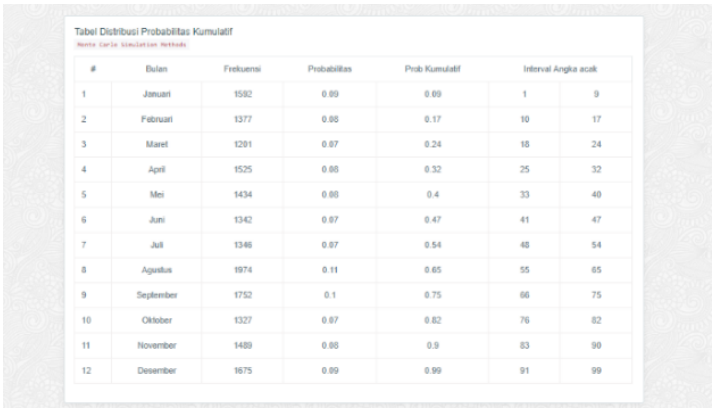

Gambar 13. Interval Angka Acak Target 2018

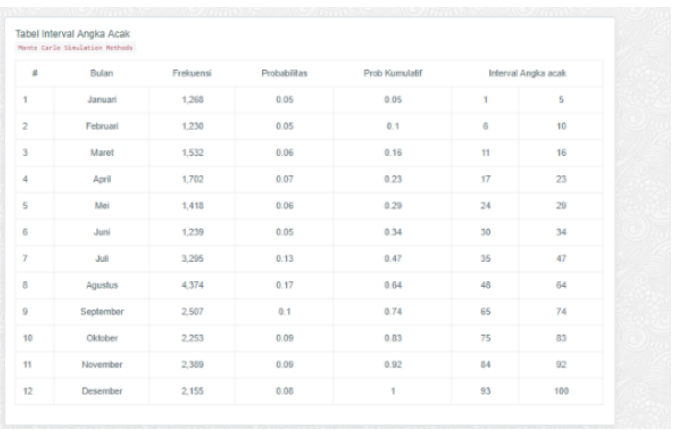

Gambar 14. Interval Angka Acak Target 2019
11. Input parameter bilangan acak

Setelah interval angka acak ditetapkan, langkah selanjutnya adalah membangkitkan bilangan acak dengan menggunakan metode Mixed Congruent Method.

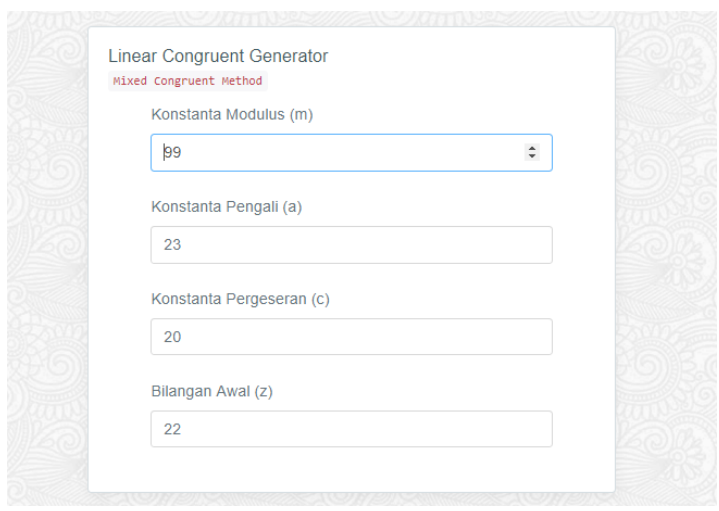

Gambar 15. Input Parameter Angka Acak

12. Bilangan acak

Berdasarkan nilai parameter yang telah diinputkan pada form yang ada pada gambar 15, maka diperoleh beberapa angka acak (random) seperti yang terlihat pada gambar 16.

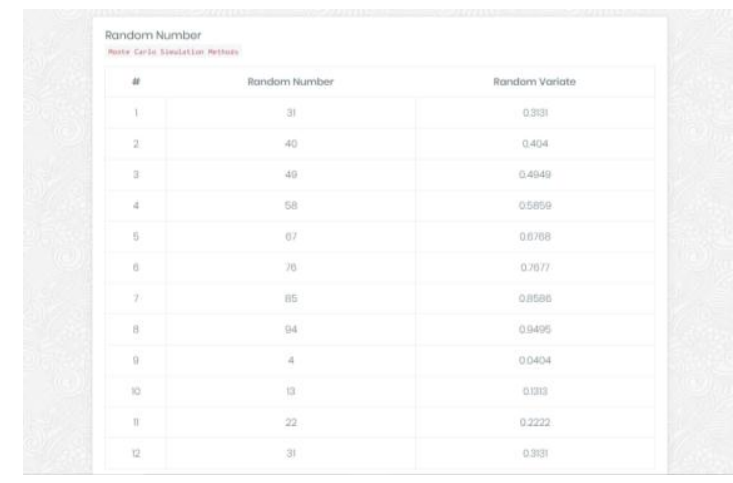

\section{Gambar 16. Bilangan Acak (Random} Number) 
13. Hasil simulasi

Setelah melewati beberapa langkah di atas, maka diperoleh hasil prediksi jumlah kunjungan pasien.

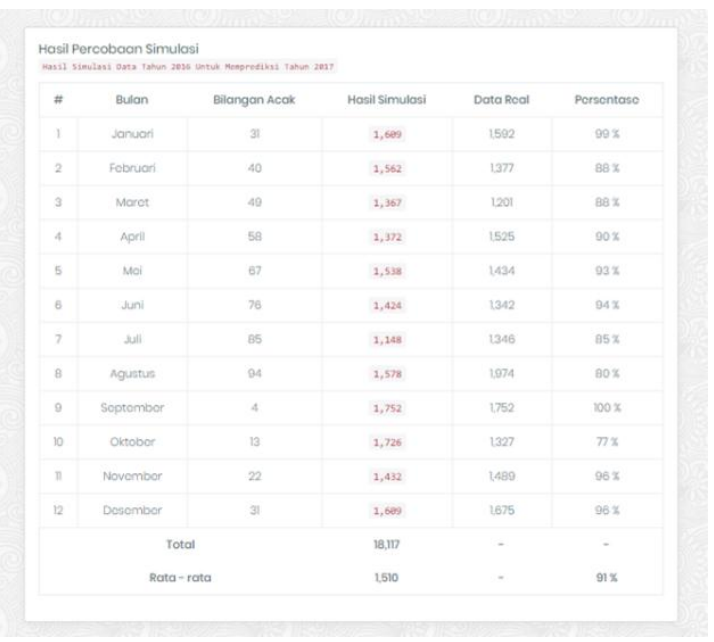

Gambar 17. Hasil Simulasi Tahun 2017

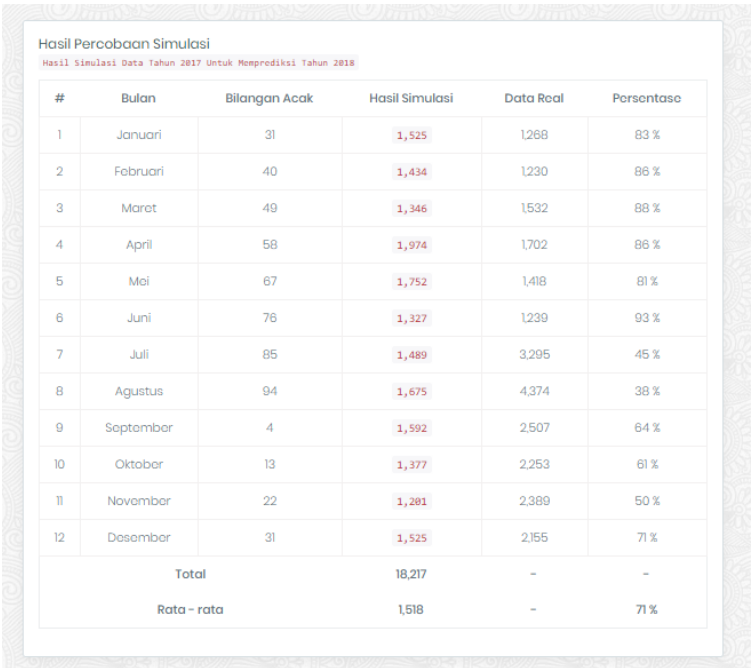

Gambar 18. Hasil Simulasi Tahun 2018

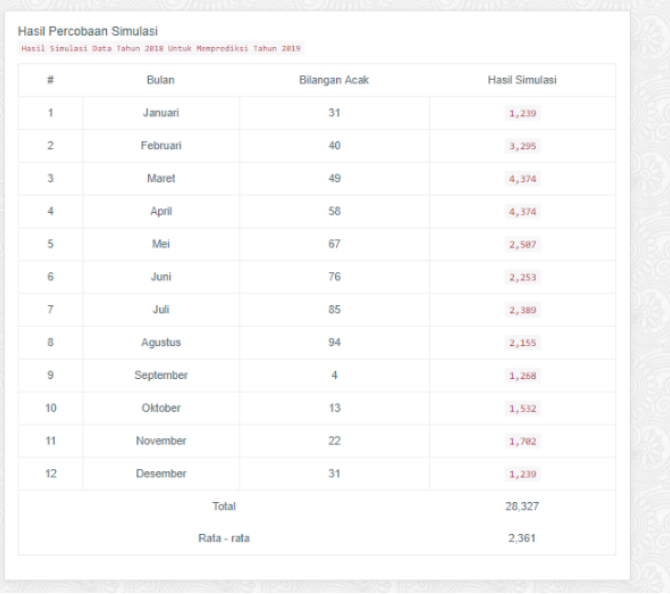

Gambar 19. Hasil Simulasi Tahun 2019

Pada gambar, hasil yang ditampilkan oleh sistem sama dengan hasil yang diperoleh berdasarkan perhitungan manual dari bab sebelumnya. Pada bulan januari 2017 gambar 17 hasil prediksi jumlah pasien yang didapatkan adalah 1609 pasien, nilai tersebut sama dengan nilai hasil simulasi tahun 2017 yang ada pada tabel 12 . Begitu juga dengan bulan pada tahun lainnya, hasil yang diperoleh oleh sistem yang dibangun sama dengan hasil perhitungan manual yang telah dilakukan sebelumnya.

\section{SIMPULAN}

Simulasi dengan metode Monte Carlo ini sangat cocok digunakan untuk melakukan simulasi untuk memprediksi jumlah kunjungan pasien untuk masa akan datang. Hasil dari simulasi dapat memberikan info kepada pihak puskesmas dan digunakan sebagai acuan dalam pengambilan kebijakan kedepannya.

\section{UCAPAN TERIMA KASIH}

Terimakasih kepada اله atas segala rahmat dan karunia yang telah di berikan kepada saya, terima kasih kepada nabi Muhammad orang tua, dosen 
pembimbing yang telah membantu dalam penyusunan jurnal ini, pihak puskesmas yang bersedia memberikan data penelitian dan tidak lupa saya terima kasih kepada keluarga dan terima kasih untuk semua yang mendukung penelitian ini.

\section{DAFTAR PUSTAKA}

[1] Yuniar, E., Muslim, M.H., 2018. Sistem Informasi Layanan Kesehatan Dengan Menggunakan Codeigniter Pada Puskesmas Bululawang. Antivirus: Jurnal Ilmiah Teknik Informatika 12. doi:10.30957/antivirus.v12i1.429

[2] Kumala, I., Sukania, I.W., Christianto, S., 2016. Optimasi Persediaan Spare Part untuk Meningkatkan Total Penjualan Dengan Menggunakan Simulasi Monte Carlo (Studi Kasus di PT. ZXC). Jurnal Ilmiah Teknik Industri 4, 166-174.

[3] Hutahaean, H.D., 2018. Analisa Simulasi Monte Carlo untuk Memprediksi Tingkat Kehadiran Mahasiswa Dalam Perkuliahan. Journal of Informatic Pelita Nusantara 3, 41-45. doi: 10.1016/j.ejca.2005.10.031

[4] Nasution, K.N., 2016. Prediksi Penjualan Barang Pada Koperasi Pt.Perkebunan Silindak Dengan Menggunakan Metode Monte Carlo. JURIKOM (Jurnal Riset Komputer) 3, 65-59.

[5] Liu, J., Qi, Y., ... Fu, L., 2017. Selflearning Monte Carlo method. Physical Review $\mathrm{B}$ 95. doi:10.1103/PhysRevB.95.041101

[6] Dharwiyanti, S., Satria Wahono, R., 2003. Pengantar Unified Modeling Langange (UML). Journal of Cataract and Refractive Surgery 13. doi:10.1016/j.jcrs.2009.09.016

[7] Hutahaean, H.D., 2018. Analisa Simulasi Monte Carlo untuk Memprediksi Tingkat Kehadiran Mahasiswa Dalam Perkuliahan. Journal
Of Informatic Pelita Nusantara 3, 41-45. doi:10.1016/j.ejca.2005.10.031

[8] Nashrulhaq, M. I., Nugraha, C., \& Imran, A. (2014). Model Simulasi Sistem Antrean Elevator *. Jurnal Online Instut Teknologi Nasional, 2(Model Simulasi), 121-131.

[9] Saragih O., Sianturi L. T., Siburian H. K. dan Suginam, 2016. Simulasi Antrian Penerimaan Bantuan Langsung Tunai (Blt) Dengan Menerapkan Algoritma First In First Out: Jurnal Riset Komputer (JURIKOM), Vol. 3 No. 6, 115-118

[10] Satria, R., Sovia, R. Dan Gema, R., L. (2017). Pemodelan Dan Simulasi Analisa Sistem Antrian Pelayanan Nasabah Di Pt Sarana Sumatera Barat Ventura Ssbv Menggunakan Metode Monte Carlo. Jurnal KomTekInfo Vol. 4, No. 1, Juni 2017, Hal. 116-128

[11]SILALAHI, Mesri. Perbandingan Performansi Database Mongodb Dan Mysql Dalam Aplikasi File Multimedia Berbasis WEB. Computer Based Information System Journal, [S.1.], v. 6, n. 1, p. 63, mar. 2018. ISSN 2621-5292.

[12] Peranginangin, Kasiman. 2006. Aplikasi WEB dengan PHP dan MySQL. Yogyakarta: Andi. 